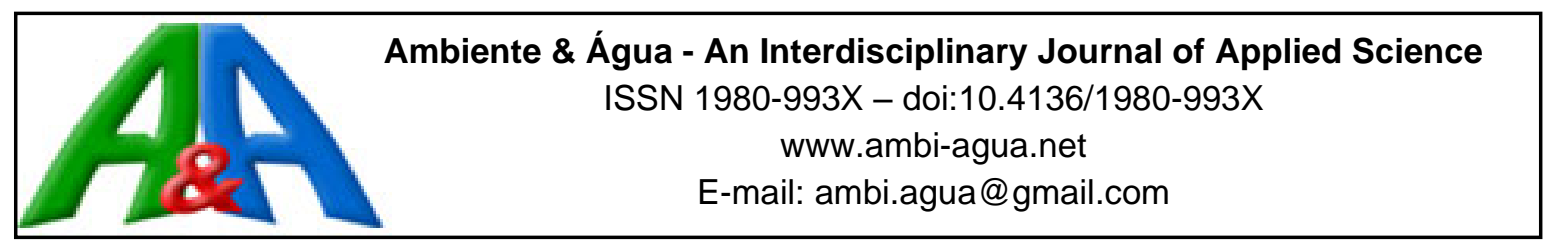

\title{
Occurrence of 17a-ethinylestradiol in Paranoá Lake watershed (Brasília, Brazil): sewage, freshwater and treated water
}

\author{
ARTICLES doi:10.4136/ambi-agua.2686
}

Received: 14 Dec. 2020; Accepted: 21 Jun. 2021

\begin{abstract}
Juliana Pinheiro Gomes ${ }^{1} \mathbb{D}_{\text {; }}$ Giulia Oliveira Timo² ${ }^{\mathfrak{D}}$; Lícia Murito de Paula1 ${ }^{1}$; Thales Viana Labourdette Costa ${ }^{2}$; Paulo Roberto de Souza Rocha Júnior ${ }^{2}{ }^{\circledR}$; Mauricio Homem de Mello ${ }^{2}$; Jaime Lopes da Mota Oliveira ${ }^{* * i D}$
\end{abstract}

${ }^{1}$ Escola Nacional de Saúde Pública Sergio Arouca. Fundação Oswaldo Cruz (Fiocruz), Rua Leopoldo Bulhões, n 1480, CEP: 21041-210, Manguinhos, RJ, Brazil. E-mail: julianapinheiro2011@gmail.com, liciamurito@gmail.com ${ }^{2}$ Departamento de Farmácia. Faculdade de Ciências da Saúde. Universidade de Brasília (UnB), Campus Universitário Darcy Ribeiro, s/n, Asa Norte, CEP: 70910-900, Brasília, DF, Brazil. E-mail: giulia.timo@aluno.unb.br, thalesvn1@gmail.com, profpaulorochajr@gmail.com, mauriciohmello@unb.br

${ }^{3}$ Departamento de Saneamento e Saúde Ambiental. Escola Nacional de Saúde Pública Sérgio Arouca. Fundação Oswaldo Cruz (Fiocruz), Rua Leopoldo Bulhões, n¹480, CEP: 21041-210, Rio de Janeiro, RJ, Brazil.

*Corresponding author. E-mail: jaimel@ensp.fiocruz.br

\begin{abstract}
Emerging contaminants such as $17 \alpha$-ethynylestradiol (EE2) can be discharged from sewage systems and contaminate water supplies. Paranoá Lake is a strategic water reservoir in Brasília (Brazil) that receives treated sewage from sewage treatment plants (STPs) and has recently become a water supply. This study monitored EE2 residues in different matrices from Paranoá Lake watershed using the ELISA method. This monitoring was performed together with the local environmental agency in two periods. EE2 was detected in all sewage samples showing that this residue is continually being discharged into the lake. However, EE2 was found in only one freshwater sample $(0.07 \mathrm{ng} \mathrm{L}-1)$, which is below the predicted no-effect concentration considered as a risk for aquatic animals. EE2 was not detected in treated water. Nevertheless, the increased use of freshwater as a water supply signals the need for continuous EE2 monitoring in the lake.
\end{abstract}

Keywords: endocrine disruptor, Paranoá Lake, 17 $\alpha$-ethinylestradiol.

\section{Ocorrência do 17a-ethinilestradiol na bacia do Lago Paranoá (Brasília, Brasil): esgoto, água do lago e água tratada}

\section{RESUMO}

Contaminantes emergentes como o 17 $\alpha$-etinilestradiol (EE2) podem ser descartados através dos sistemas de esgotamento sanitário e contaminar as fontes de água. O Lago Paranoá é um reservatório estratégico de Brasília (Brasil) que recebe efluentes tratados de estações de tratamento de esgotos (ETE) e, recentemente, tem sido usado como fonte de abastecimento público. Este estudo monitorou diferentes matrizes da bacia do Lago Paranoá usando o método de Elisa. Este monitoramento foi realizado junto à agência ambiental local em dois períodos. $\mathrm{O}$ 
EE2 foi detectado em todas as amostras de esgoto mostrando que este resíduo está continuamente sendo descartado no lago. No entanto, o EE2 foi encontrado em somente uma amostra da água do lago $\left(0,07 \mathrm{ng} \mathrm{L}^{-1}\right)$, que foi abaixo da concentração preditiva sem efeito considerada como de risco para animais aquáticos. O EE2 não foi detectado na água tratada. Mesmo assim, o aumento no uso da água do lago para abastecimento público indica a necessidade de um monitoramento contínuo de EE2 no lago.

Palavras-chave: disruptores endócrinos, Lago Paranoá, 17 $\alpha$-ethinilestradiol.

\section{INTRODUCTION}

Emerging pollutants are natural or anthropic chemical substances whose monitoring in the environment is not recommended by legislation in most countries, even though they display the potential to cause adverse ecological and human health effects (Gavrilescu et al., 2015). Studies have demonstrated that these substances, even at low concentrations $\left(\mu \mathrm{g} \mathrm{L}^{-1}\right.$ and $\left.\mathrm{ng} \mathrm{L}^{-1}\right)$, can cause different impacts on wild biota (Briciu et al., 2009; Jorgensen and Halling-Sorensen, 2000; Robinson and Hellou, 2009). However, little is known about the long-term effects of exposure to low concentrations of these pollutants on both the aquatic biota and humans (Huerta et al., 2012).

Interest in endocrine disruptors is increasing when emerging pollutants are evaluated. They are exogenous substances that exhibit the potential to alter endocrine system functions. These substances can mimic natural hormones, binding to receptor sites, activating, blocking and altering the cell signalling pathways that trigger hormonal function and thus interfering with the synthesis, secretion, transport, binding, action or elimination of natural hormones (Gaido et al., 1997).

This group includes, among others, 17 $\alpha$-ethinylestradiol (EE2), a synthetic estrogenic hormone developed from the addition of an ethinyl group to the 17 $\beta$-estradiol molecule in carbon 17. This derivative displays greater estrogenic potential and stability than natural hormones (Combalbert and Hernandez-Raquet, 2010; IARC, 2007; WHO, 2013). This characteristic, associated with its high hydrophobicity (log $\left.\mathrm{K}_{\mathrm{ow}} 3.67-4.15\right)$, shows its potential regarding environmental persistence and bioaccumulation (Lai et al., 2002; van Vlaardingen, 2007). EE2 is clinically used as a contraceptive in the treatment of perimenopause symptoms, postpartum breast obstruction, uterine bleeding, hormonal therapy for women with hypogonadism, and in palliative therapy for malignant prostate and breast carcinomas (Cogliano et al., 2005; Lucena, 2013).

Exposure to EE2 can trigger an increase in vitellogenin production in both male and female fish, increasing the proportion of intersex fish and decreasing the production of eggs and sperm, with low gamete quality. It may also cause feminization of male fish, reducing fertility and egg hatching. Behavioural changes in mating have also been associated with EE2 exposure in fish, amphibians, crustaceans and gastropods (Aris et al., 2014; Birnbaum, 2013; Garmshausen et al., 2015; Giusti et al., 2014; Luna et al., 2015; Metcalfe et al., 2001; Silva et al., 2013). One way to evaluate the risk of exposure of aquatic organisms to chemical compounds is by the predicted-no-effect concentration (PNEC), recently revised by Caldwell et al. (2012), who suggested a value of $0.1 \mathrm{ng} \mathrm{L}^{-1}$. PNEC is the maximum concentration of a particular chemical substance in which the organisms are protected and it is usually used by some environmental agencies such as the USEPA (2009) (Ghekiere et al., 2013; Jin et al., 2012; Lam and Gray, 2001).

The primary source of EE2 in water reservoirs is the discharge of urban sewage, as $40 \%$ of this compound is excreted in urine and 60\% in feces (Stanczyk et al., 2013). The estimated excretion of this hormone by one woman during replacement therapy or when using oral contraceptives is in the range of 7.15 to $9.10 \mu \mathrm{g}$ day $^{-1}$ (Johnson et al., 2000). However, most 
sewage treatment processes are not designed to remove some organic micro- or nano-pollutants, so these contaminants may be released in water supplies, exposing wildlife and humans through water consumption.

Brasília is the capital of Brazil and is located in its central plateau region. Due to its geographical position, safe water sources have become a challenge. Paranoá Lake is an artificial urban lake strategically constructed in 1959 to guarantee the city's water supply. It is used as well for other activities such as sports, recreation, and power generation. The lake contains a dam and receives affluent contributions from small rivers and local drainage networks. Three sewage treatment plants (STP) discharge treated urban sewage into the lake, namely STP A (the largest plant), with a flow rate of $1,319 \mathrm{~L} \mathrm{~s}^{-1}$, and STPs B and $\mathrm{C}$ that operate at flow rates of 450 and $46 \mathrm{~L} \mathrm{~s}^{-1}$, respectively. In 2016, a historical long drought hit the city, which hampered the local water supply for the human population. To solve this problem, a water treatment plant was quickly installed to capture an average of $700 \mathrm{~L} \mathrm{~s}^{-1}$ of water from Paranoá Lake to supply about 200 thousand people.

In this context, the main goal of this study was to monitor EE2 residues from raw sewage up to potable water in the Paranoá Lake watershed. Different matrices were collected and EE2 residues were determined by the ELISA (Enzyme Linked Immunosorbent Assay) methodology. To the best of our knowledge, this is the first study carried out at Paranoá Lake using the ELISA detection methodology to monitor the occurrence of EE2 in the local drainage network.

\section{MATERIALS AND METHODS}

\subsection{Sampling}

Two collection campaigns were carried out in the rainy (April) and dry (June) seasons of 2018. Samples were collected at 13 different points in each campaign (Figure 1). These samplings were performed together with the local environmental agency (Superintendence of Water Resources, Water and Sanitation Regulatory Agency of the Federal District), and only one sample (1 liter) per point was collected (single sampling). Raw (P1, P3 and P5) and treated (P2, P4 and P6) sewage were collected at treatment plants A (P1 and P2), B (P3 and P4) and C (P5 and P6). Sewage treatment plants (STP) A and B use Phoredox 3-stages (anaerobic-anoxicoxic) also called A2O (von Sperling, 2012) followed by a physicochemical precipitation method, while STP C operates using a sequential batch reactor (SBR) with only an aerobic phase followed by physicochemical precipitation methods. These plants were initially built for phosphorus removal. Freshwater samples from Paranoá Lake were collected from the superficial layer (photic layer), and this depth is the same used by the local environmental agency in their monitoring program (up to 1 meter). Samples were collected from upstream to downstream of the sewage discharging points (P7, P8, P9 and P12) close to the dam, where a new water treatment plant is planned (P11), as well as close to the water treatment catchment point (P10). Finally, a treated water sample from the water treatment plant (P13) was also collected. The water treatment plant began operating at the end of 2017 and uses a nanofiltration system.

The Paranoá Lake samples were characterized as follows: dissolved oxygen (DO) concentration, conductivity, $\mathrm{pH}$, turbidity and temperature, using a multiparametric EXO 1 probe (YSI - Xylem Inc. Ohio, USA). Total coliforms and E. coli were determined by the multiple-tube technique. All analyses were performed as recommended by Standard Methods (APHA et al., 2017). The physicochemical characterization of the raw and treated sewage and treated water samples were conducted by the local Sewage and Water Company, while the microbiological tests were performed by our staff in the Microbial Quality Control facility of the Natural Products Laboratory at the University of Brasilia (LaProNat - UnB). Regarding the EE2 evaluation, the collected samples were preserved in amber glass bottles containing methanol $(0.1 \%)$ and stored at $4^{\circ} \mathrm{C}$ in a cold chamber until their analysis, all performed on the 
same day.

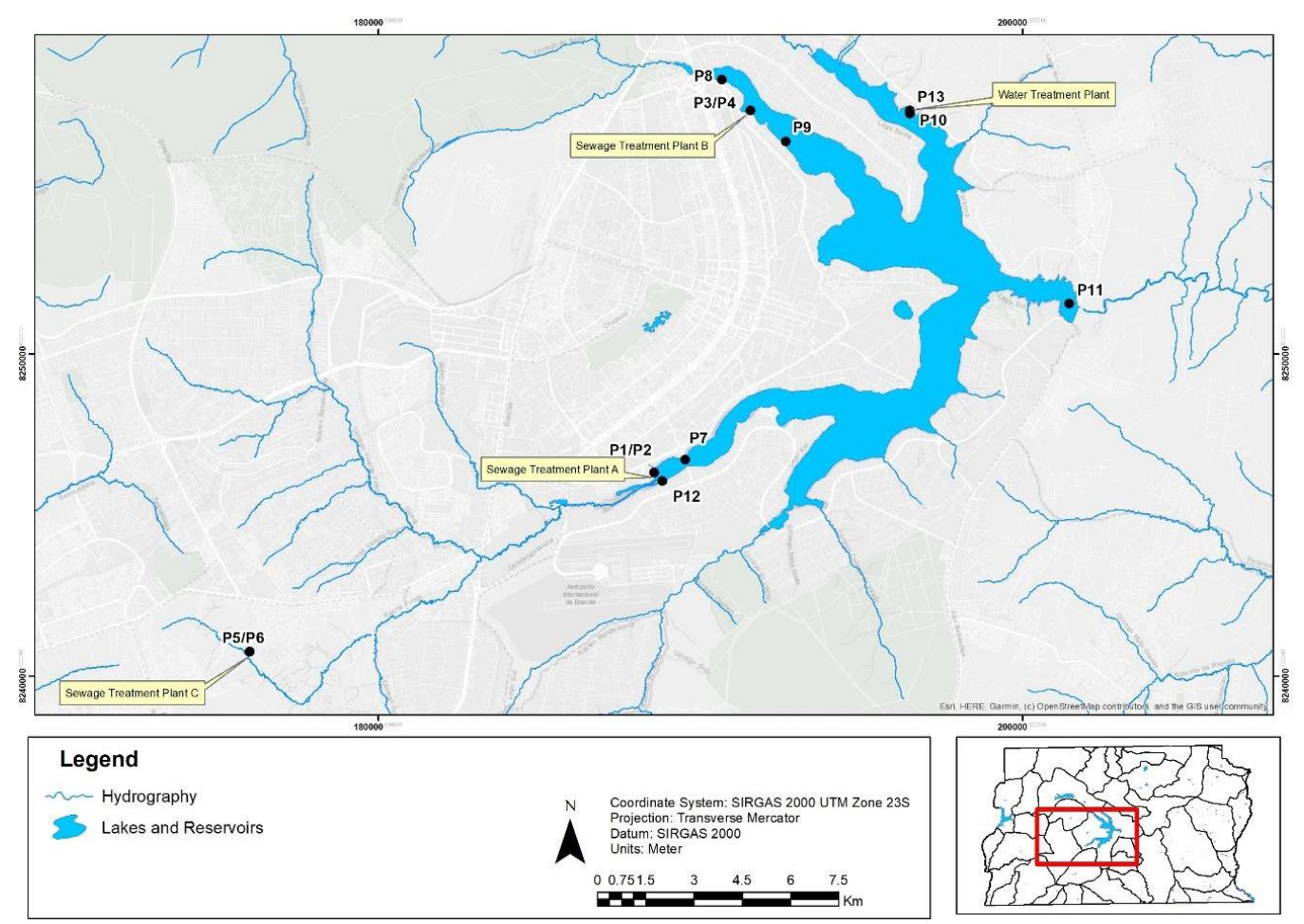

Figure 1. Image of Paranoá Lake, displaying its contributors and different sampling points (freshwater, raw and treated sewage and treated water).

\subsection{ELISA analysis}

Samples were analyzed in analytical duplicate using the ELISA (Enzyme Linked Immunosorbent Assay) enzyme assay (Abraxis Ecologiena, Tokiwa Chemical Industries, Tokyo/Japan kit). This competitive and direct test has been validated in the literature (Huang and Sedlak, 2001; Silva et al., 2013) and is recommended by the United States Environmental Protection Agency (USEPA, 2009).

First, freshwater samples from Paranoá Lake were directly analyzed, with no pretreatment, since this method is adequate for samples in complex matrices such as water, freshwater and sewage (Silva et al., 2013). However, the low concentrations of EE2 usually detected in this kind of matrix led to the need for a pre-treatment, where the samples were filtered and then concentrated up to 1,000 times using solid-phase extraction (SPE) C18 cartridges (Figure 2).

The pre-treatment is a common analytical procedure used to increase the sensitivity of the method as well as the limit of quantification and detection of EE2 $\left(0.05 \mathrm{ng} \mathrm{L}^{-1}\right.$, range $0.05-3.0$ $n \mathrm{~L} \mathrm{~L}^{-1}$ ) being recommended by the assay manufacturer. This method is highly reproducible and sensitive, with a maximum coefficient of variation of $10 \%$ through samples. All EE2 analyses were performed in duplicates, and the result was accepted if the values did not differ more than $5 \%$ one from each other. In this assay, the intensity of color is higher as the concentration in the sample lowers. The maximum color possible to be developed is achieved in the blank control (absence of EE2). Quantification and detection limits are, in this method, defined by the lowest concentration available as standard $\left(0.05 \mathrm{ng} \mathrm{L}^{-1}\right)$. The upper limit of quantification is characterized by the least intense color development possible to be detected within the linear range (3.0 ng L ${ }^{-1}$ ) (Ecologiena, 2017).

Furthermore, this method had been recommended in monitoring programs by USEPA (2009) because it is comparable with traditional methods such as chromatography. After pretreatment, the analysis methodology was conducted according to the manufacturer's 
recommendations.

Briefly, the method is based on a competitive ELISA procedure. After resuspension, samples are quantitatively $(1: 1)$ mixed to an EE2 conjugate (with HRP - Horse Radish Peroxidase) and then incubated in a microplate coated with monoclonal EE2 antibodies. After rinsing, color is developed through the oxidation of 3,3',5,5'-tetramethylbenzidine (TMB) to 3,3',5,5'-tetramethylbenzidine diamine, a blue pigment (Ecologiena, 2017). After stopping the reaction using a citric acid solution, the color changes to yellow, and the maximum absorbance of the diamine product moves to 450nm (Bally and Gribnau, 1989), the wavelength used to read samples on an Enspire ${ }^{\circledR} 2300$ plate reader (Perkin Elmer - PerkinElemer Inc. Waltham, USA).

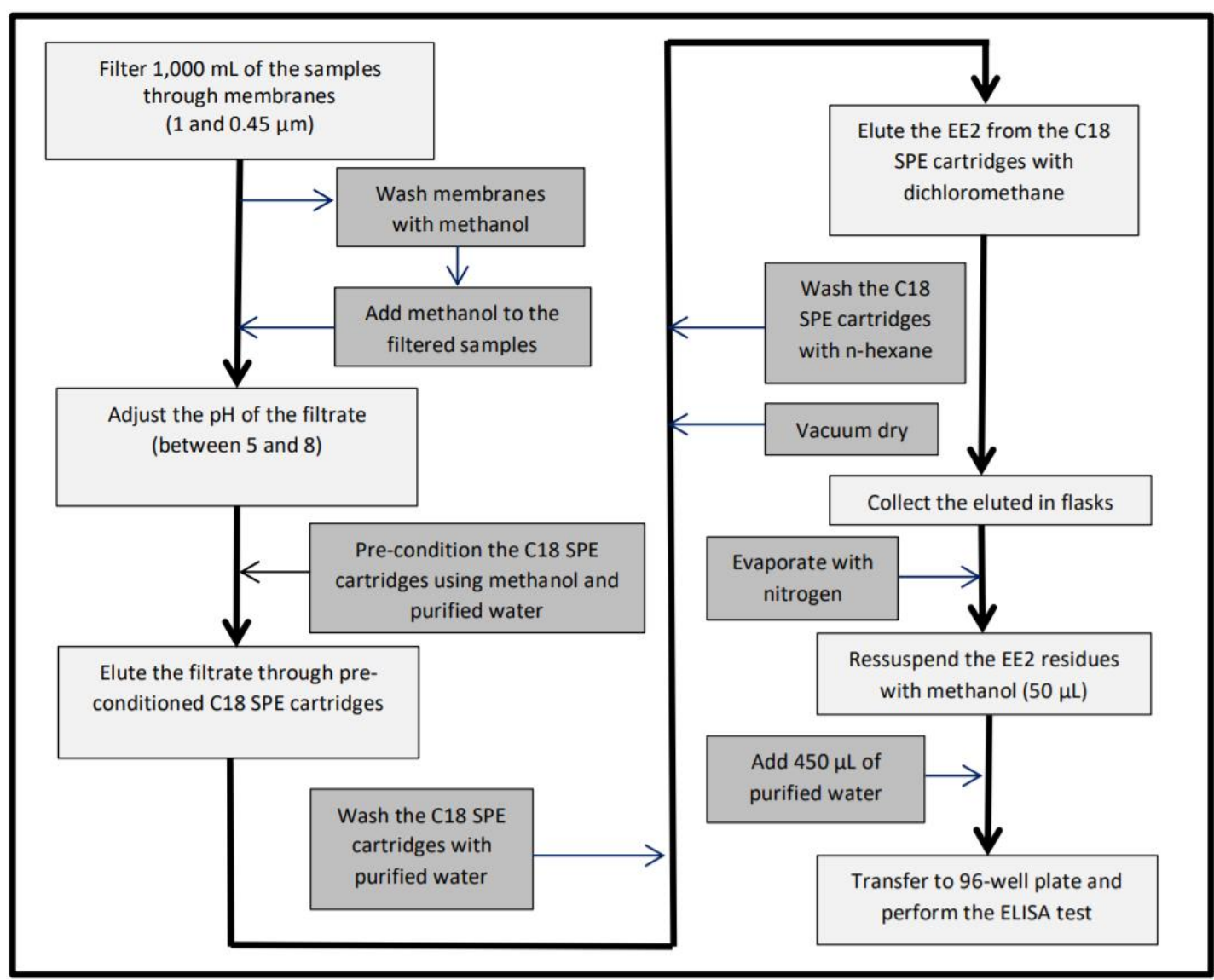

Figure 2. Sample flowchart pre-treatment for analysis by the ELISA method.

\section{RESULTS AND DISCUSSION}

\subsection{EE2 residues in sewage samples}

EE2 residues were detected in all sewage samples (Table 1). The EE2 values in raw sewage (P1, P3 and P5) ranged between 1.31 and $2.08 \mathrm{ng} \mathrm{L}^{-1}$, close to values reported in the literature in raw sewage from other countries, but lower than those reported in other studies in Brazil (Pessoa et al., 2014; Queiroz et al., 2012). For example, Auriol et al. (2006) reported a range between 3 and $7.1 \mathrm{ng} \mathrm{L}^{-1}$ of EE2 in raw sewage from some European countries, and Luo et al. (2014) reported EE2 concentrations in raw sewage between 1 and $3 \mathrm{ng} \mathrm{L}^{-1}$ in different European countries, Asia and the United States. Cunha et al. (2017) reported a range between 12.4 and $3,180 \mathrm{ng} \mathrm{L}^{-1}$ for EE2 in raw sewage in different areas in Brazil. These variations in EE2 concentrations in raw sewage may occur due to differences in birth control and public health policies (Jafari et al., 2009). In this case, regions that adopt contraceptive pills as birth control will probably exhibit higher EE2 concentrations. 
Table 1. Characterization and EE2 concentrations of raw and treated sewage samples from Sewage Treatment Plants (STP).

\begin{tabular}{|c|c|c|c|c|c|c|c|c|c|c|c|c|c|}
\hline \multicolumn{14}{|c|}{ Sewage from STP } \\
\hline \multirow{3}{*}{ Parameter } & & \multicolumn{6}{|c|}{ April } & \multicolumn{6}{|c|}{ June } \\
\hline & & $\mathrm{P} 1$ & $\mathrm{P} 2$ & $\mathrm{P} 3$ & $\mathrm{P} 4$ & P5 & P6 & $\mathrm{P} 1$ & $\mathrm{P} 2$ & P3 & $\mathrm{P} 4$ & P5 & P6 \\
\hline & & \multicolumn{2}{|c|}{ STP A } & \multicolumn{2}{|c|}{ STP B } & \multicolumn{2}{|c|}{ STP C } & \multicolumn{2}{|c|}{ STP A } & \multicolumn{2}{|c|}{ STP B } & \multicolumn{2}{|c|}{ STP C } \\
\hline $\begin{array}{c}\text { Biochemical oxygen } \\
\text { demand }\end{array}$ & $\left(\mathrm{mg} \mathrm{L}^{-1}\right)$ & 284.5 & 10.0 & 317.8 & 2.5 & 464.8 & 8.5 & 377.0 & 5.8 & 522.0 & 4.3 & 626.7 & 8.8 \\
\hline Chemical oxygen demand & $\left(\mathrm{mg} \mathrm{L}^{-1}\right)$ & 576.6 & 46.5 & 612.3 & 38.3 & 850.7 & 53.5 & 534.9 & 33.3 & 838.6 & 39.8 & 890.9 & 64.9 \\
\hline Total phosphorus & $\left(\mathrm{mg} \mathrm{L}^{-1}\right)$ & 7.9 & 0.7 & 7.3 & 0.3 & 8.8 & 0.4 & 8.5 & 0.3 & 9.0 & 0.2 & 9.6 & 0.7 \\
\hline Suspended solids & $\left(\mathrm{mg} \mathrm{L}^{-1}\right)$ & 256.2 & 18.6 & 272.7 & 9.4 & 292.2 & 49.7 & 268.3 & 5.9 & 382.0 & 8.3 & 214.9 & 66.6 \\
\hline EE2 & $\left(\operatorname{ng~L^{-1}}\right)$ & 1.43 & 0.83 & 1.34 & 0.85 & 1.85 & 0.23 & 1.55 & 1.40 & 1.31 & 0.91 & 2.08 & 1.50 \\
\hline Efficiency of EE2 removal & $(\%)$ & 42 & & 37 & & 88 & & 10 & & 3( & & & \\
\hline
\end{tabular}

Notes: the values are average; flow rates of raw sewage at STP A, B and C average 1319,450 and $46 \mathrm{~L} \mathrm{~s}^{-1}$, respectively. 
The EE2 concentrations detected in the treated (P2, P4 and P6) sewage ranged from 0.23 up to $1.50 \mathrm{ng} \mathrm{L}^{-1}$, lower than that reported by Silva (2015), of about $500 \mathrm{ng} \mathrm{L}^{-1}$ in treated sewage from the same plants evaluated in 2015. The differences observed between these two years (2015 and 2017) may be due to planning that may have forced changes in the plant operating systems. Between 2016 and 2018, Brasília was marked by water scarcity, and the solution was to use freshwater from Paranoá Lake as a water source for the local human population. This fact has probably provoked changes in the city's sewage system, which can justify these different results. It is also noteworthy that these values can fluctuate throughout the day, and this can make it difficult to assess the removal of EE2 in full-scale treatment plants, especially in a limited set of grab samples.

All sewage treatment processes are capable of removing organic matter and phosphorus, which is required by local environment agencies when the sewage is discharged into freshwater lakes. These processes must be able to remove phosphorus because this element stimulates the growth of microalgae and water plants (eutrophication). The efficiency of phosphorus removal at STP C was slightly lower than at Plants A and B (Table 1), but displayed higher efficacy in removing EE2. While the A2O systems, followed by a physicochemical precipitation method, removed between 10 and $42 \%$ of EE2, the SBR system resulted in a removal rate ranging from 28 to $88 \%$. The difference of EE2 removal observed in STP C may have occurred due to operational conditions that may modify EE2 removal mechanisms such as hydraulic detention time (HDT) (Koh et al., 2008). According to the Sewage and Water Company, the STP C may have a variable HDT due to the affluent characteristics.

Phosphorus removal requires a metabolic sequence of anaerobic steps followed by aerobic phases, with sludge release occurring during the process. To this end, these processes adopt a low sludge retention time (SRT). Hashimoto and Murakami (2009) suggested that EE2 can be adsorbed and released with the sludge during sewage treatment processes. Therefore, lower SRT may result in higher EE2 removal rates. However, studies on systems that apply higher SRT indicate that this can lead to EE2 biodegradation, facilitating the development of microorganisms capable of degrading this compound (Koh et al., 2008).

Recently, Chen et al. (2018) obtained lower hormone removal in a process with higher phosphorus removal and observed that ammonium oxidation during nitrogen removal aided to promote higher hormone removal rates. The STP C that uses the SBR system with only an aerobic stage promotes nitrification and, consequently, ammonium oxidation. This fact can explain further EE2 removal by this plant. Other studies have associated hormone removals with the nitrification process (Andersen et al., 2003; Chen et al., 2018; Joss et al., 2004; Li et al., 2020; Vader et al., 2000), but little is known about the correlation between the simultaneous removal of phosphorus and hormones. It is important to note that all STP use physicochemical precipitation processes, but coagulant chemicals do not improve hormone removal (Svenson et al., 2003).

The flow rates of the assessed plants were different. Organic loading at STP A was higher than STP B and much greater than STP C (Table 1). Previous studies have attempted to associate increased organic loading (or flow) with decreased estrogen removal efficiency (Koh et al., 2008). Thus, the highest flow rate applied at STP A may be the cause for lower EE2 removal rates when compared to STP C.

Finally, a small amount of EE2 present in treated sewage (about $1.0 \mathrm{ng} \mathrm{L}^{-1}$ ) may be released daily into Paranoá Lake. This concentration represents a risk to the aquatic environment since it can cause vitellogenin induction in male fish (Cunha et al., 2017). Therefore, further studies in real scale sewage treatment plants applying different methods (processes) are required to better elucidate this phenomenon, mainly under higher phosphorus removal rates.

\subsection{EE2 residues in water from Paranoá Lake}

Figure 3 displays the georeferencing of the EE2 sampling locations in different seasons. 
Among surface water samples, EE2 residues were detected only at P7 in June (Table 2). The quantification of EE2 at this point during the dry season corroborates Sodré et al. (2018), who identified significantly higher concentrations for other emerging contaminants analyzed during the same season in Brazil. Sodré and Sampaio (2020) found EE2 in drinking water from Paranoá Lake using liquid chromatography coupled to a mass spectrometry detector, with a limit of detection between 1.12 and $1.46 \mathrm{ng} \mathrm{L}^{-1}$. Methods such as liquid or gas chromatography are excellent for multi-residues analysis, while the ELISA method consist of a link between an antibody and specific antigens, is not usually influenced by the matrix effect, and displays good sensitivity (Huang and Sedlak, 2001; Silva et al., 2013).

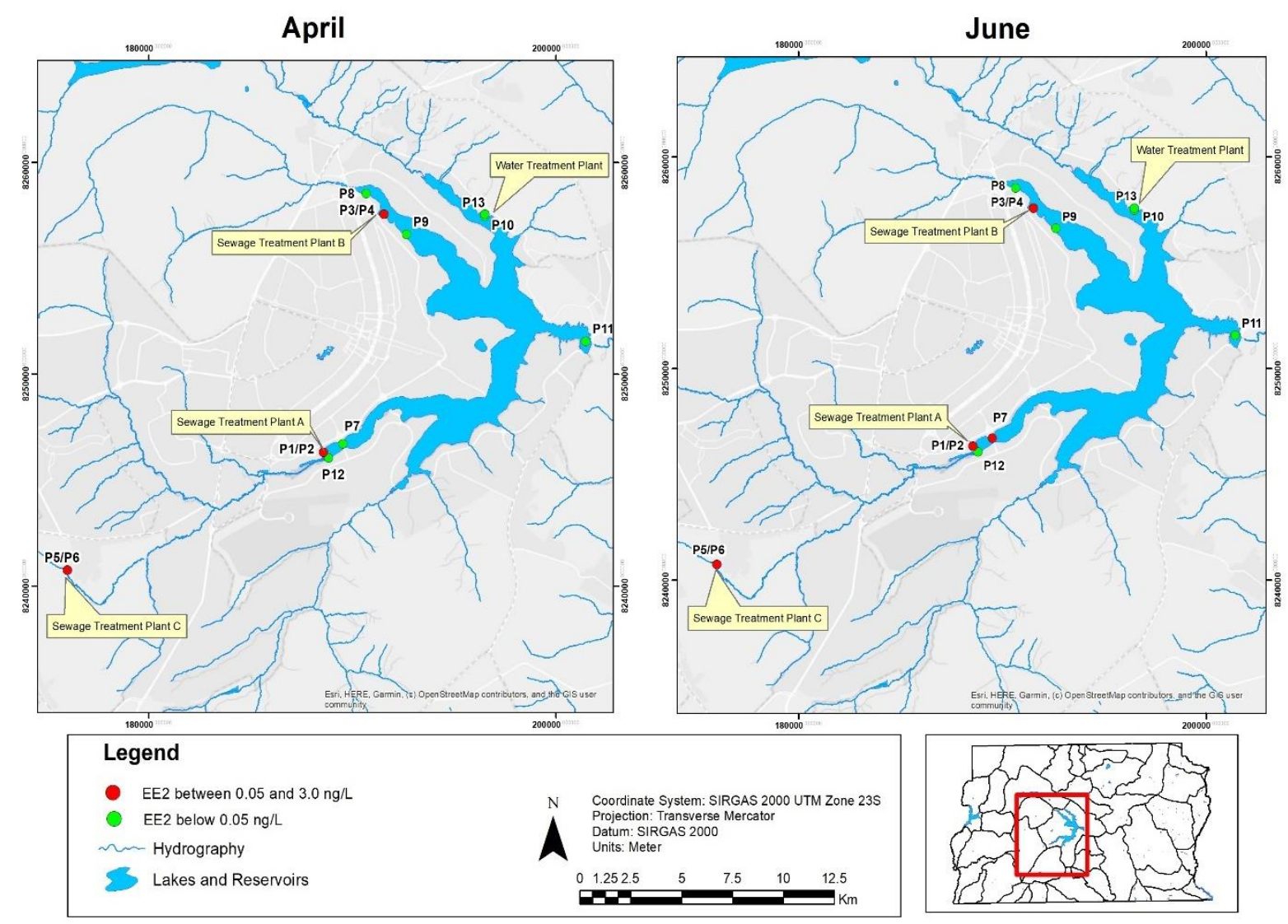

Figure 3. Image of Paranoá Lake indicating the sampling points where EE2 residues were detected.

The EE2 quantification noted at P7 is probably due to sewage discharge, as this point is located downstream of STP A. In June, the EE2 concentration in the treated sewage from this plant was higher (Table 1). Furthermore, P7 is located near the exit of the city's drainage system, which can release EE2 residues in the case of untreated sewage disposal (clandestine discharge). While P9 is situated close to the treated sewage disposal point (downstream of STP B), EE2 was not detected at this point. Similar to P7, P8 and P12 also exhibited higher E. coli concentrations (Table 2), suggesting possible sewage input, although EE2 residues were not detected at these points. Even if all locations may receive EE2 residues alongside raw or treated sewage release, these residues were not detected in the superficial freshwater layer.

The EE2 concentration of $0.07 \mathrm{ng} \mathrm{L}^{-1}$ detected in P7 was slightly below the value that represents a risk of exposure to aquatic organisms as recommended by Caldwell et al. (2012). 
Table 2. Characterization and EE2 concentrations of freshwater samples from Paranoá Lake.

\begin{tabular}{|c|c|c|c|c|c|c|c|c|c|c|c|c|c|}
\hline \multicolumn{14}{|c|}{ Sampling of Paranoá Lake } \\
\hline \multirow{2}{*}{\multicolumn{2}{|c|}{ Parameter }} & \multicolumn{6}{|c|}{ April } & \multicolumn{6}{|c|}{ June } \\
\hline & & P7 & P8 & P9 & $\mathrm{P} 10$ & $\mathrm{P} 11$ & $\mathrm{P} 12$ & P7 & P8 & P9 & $\mathrm{P} 10$ & P11 & $\mathrm{P} 12$ \\
\hline $\mathrm{pH}$ & & 8.3 & 8.8 & 8.9 & 8.7 & 8.7 & 8.5 & 7.8 & 7.5 & 7.5 & 7.4 & 7.1 & 8.7 \\
\hline Temperature & $\left({ }^{\circ} \mathrm{C}\right)$ & 25.1 & 25.1 & 25.3 & 25.0 & 24.7 & 21.4 & 24.0 & 23.6 & 22.3 & 23.2 & 22.7 & 20.3 \\
\hline Dissolved oxygen & $\left(\mathrm{mg} \mathrm{L}^{-1}\right)$ & 5.7 & 6.3 & 6.2 & 6.1 & 6.7 & 7.7 & 7.2 & 7.3 & 7.2 & 7.3 & 6.6 & 7.4 \\
\hline Conductivity & $\left(\mu \mathrm{S} \mathrm{cm}{ }^{-1}\right)$ & 123 & 120 & 111 & 97 & 102 & 99 & 169 & 151 & 141 & 131 & 133 & 113 \\
\hline Turbidity & (NTU) & 25.4 & 1.1 & 0.7 & 5.0 & 1.0 & 35.2 & 4.8 & 2.4 & 1.4 & 1.4 & 0.8 & 7.6 \\
\hline Total coliforms & $\left(\mathrm{MPN} 100 \mathrm{~mL}^{-1}\right)$ & 6. $10^{4}$ & 2. $10^{4}$ & $1.10^{2}$ & 1. $10^{2}$ & 1. $10^{2}$ & 4. $10^{4}$ & 1. $10^{3}$ & 5. $10^{2}$ & 1. $10^{2}$ & 3. $10^{1}$ & 3. $10^{1}$ & 5. $10^{4}$ \\
\hline E. coli & $\left(\mathrm{MPN} 100 \mathrm{~mL}^{-1}\right)$ & 1. $10^{4}$ & 1. $10^{4}$ & $2.10^{1}$ & 1. $10^{2}$ & 4. $10^{1}$ & 1. $10^{4}$ & 2. $10^{2}$ & 4. $10^{1}$ & 1. $10^{2}$ & 3. $10^{1}$ & 3. $10^{1}$ & 9. $10^{3}$ \\
\hline EE2 & $\left(n g L^{-1}\right)$ & ND & ND & ND & ND & ND & ND & 0.07 & ND & ND & ND & ND & ND \\
\hline
\end{tabular}

Notes: the values are average; $\mathrm{ND}$ - not detected; no EE2 residues were detected in P13. 
The disparity between the EE2 concentrations detected in the treated sewage discharge and in the samples collected directly from the lake may be related to natural EE2 attenuation processes, such as dilution and/or eventual sorption in suspended solids and sediments. EE2 is a hydrophobic molecule $\left(\log \mathrm{K}_{\mathrm{ow}} 3.67\right.$ - 4.15) that tends to sorb to sediments, suspended particles and organic matter present in water (Auriol et al., 2006; Cunha et al., 2017; Tiedeken et al., 2017; Zhang and Zhou, 2008). Samplings from the deepest parts of Paranoá Lake may demonstrate higher concentrations of this micropollutant, since EE2 is consistently being discharged in wastewater treatment plants, and the possibility of EE2 suspension in the water column should be taken into account, resulting in bioavailability.

P11 is located near a dam where a new water treatment plant will be built, while P10 comprises the lake's water intake point. Both points exhibited low sewage contamination (low E. coli concentrations) and no EE2 residues were detected. While P10 is the upstream point of the north side of the Paranoa Lake and receives water from a drainage system more preserved (Gama and Torto Streams System), P11 point is downstream Paranoá Lake and receives all drainage systems of the city (Liporoni, 2012). Therefore, the use of P11 as a future catchment point for water treatment can be a problem.

EE2 was also not detected in the treated water from the water treatment plant (P13), in contrast with Sodré and Sampaio (2020), who reported EE2 residues in treated water from this plant in 2017 (one year before the present study). In 2017, this plant was about to begin operations, and some installation adjustments were still being finalized. It is possible that these adjustments led to the suspension of particulate material from the bottom of the lake, leading to these discrepant results. The nanofiltration process has the capacity to remove EE2 (Boussahel et al., 2000; Kasner, 2011), although this may vary depending on input concentrations. The suspension of particulate material from the bottom of the lake can harm this process, resulting in higher EE2 concentrations in treated water.

Considering the local population growth, the concentrations of emerging pollutants at Paranoá Lake could increase. In order to minimize the negative impacts on aquatic biota and ensure water quality, continuous monitoring of EE2 residues in freshwater is recommended. Some international laws already recommended the analysis of EE2 residues in water reservoirs and/or treated water (Cunha et al., 2016). The ELISA method may be employed as the standard method to this end, since it is a more practical approach and generates fewer residues than traditional chromatography methods.

\section{CONCLUSIONS}

The EE2 concentrations determined in raw and treated sewage discharged in Paranoá Lake were lower than other reports elsewhere in Brazil, but within the normal range described by other studies worldwide.

The biological processes used to treat urban sewage remove only a small amount of EE2 residues. The sequential batch reactor assessed herein displays higher EE2 removal performance than the Phoredox (A2O) system. Despite EE2 removal rate efficiency (ranging 10 to $88 \%$ ), the treated sewage evaluated in this study contained an average concentration of $1.0 \mathrm{ng} \mathrm{L}^{-1}$ for this hormone, which may represent an environmental risk to the biota of Paranoá Lake, according to the adverse effects for this compound reported in other studies.

The EE2 concentrations in the surface water samples (photic layer) from Paranoá Lake and treated water were below $0.05 \mathrm{ng} \mathrm{L}^{-1}$. Only one lake sampling point contained EE2 residues, possibly due to sewage discharge.

The ELISA method has proved to be a very sensitive and practical approach for monitoring EE2 residues in different matrices. 


\section{ACKNOWLEDGEMENTS}

Authors would like to thank Prof. Pérola de Oliveira Magalhães for providing the laboratory structure needed for this study. We also thank the Superintendence of Water Resources, Water and Sanitation Regulatory Agency and Sewage and Water Company of the Federal District for their support with the sampling and The National Health Foundation (FUNASA) by its financial support (process number: 25100.015.579/2017-64).

\section{REFERENCES}

ANDERSEN, H.; SIEGRIST, H.; HALLING-SØRENSEN, B.; TERNES, T. A. Fate of Estrogens in a Municipal Sewage Treatment Plant. Environmental Science and Technology, v. 37, n. 18, p. 4021-4026, 2003. https://doi.org/10.1021/es026192a

APHA; AWWA; WEF. Standard Methods for the examination of water and wastewater. 23nd ed. Washington, 2017. 1504 p.

ARIS, A. Z.; SHAMSUDDIN, A. S.; PRAVEENA, S. M. Occurrence of 17alphaethynylestradiol (EE2) in the environment and effect on exposed biota: a review. $\begin{array}{llllll}\text { Environment International, } & \text { v. } & 6914 .\end{array}$ https://doi.org/10.1016/j.envint.2014.04.011

AURIOL, M.; FILALI-MEKNASSI, Y.; TYAGI, R.; ADAMS, C.; SURAMPALLI, R. Y. Endocrine Disrupting Compounds Removal from Wastewater, a New Challenge. Process Biochemistry, v. 41, p. 525-539, 2006. https://doi.org/10.1016/j.procbio.2005.09.017

BALLY, R. W.; GRIBNAU, T. C. Some aspects of the chromogen 3,3',5,5'tetramethylbenzidine as hydrogen donor in a horseradish peroxidase assay. Journal of Clinical Chemistry and Clinical Biochemistry, v. 27, n. 10, p. 791-796, 1989. https://doi.org/10.1515/cclm.1989.27.10.791

BIRNBAUM, L. S. State of the Science of Endocrine Disruptors. Environmental Health Perspectives, v. 121, n. 4, p. A107, 2013. https://doi.org/10.1289/ehp.1306695

BOUSSAHEL, R.; BOULAND, S.; MOUSSAOUI, K. M.; MONTIEL, A. Removal of pesticide residues in water using the nanofiltration process. Desalination, v. 132, p. 205209, 2000. https://doi.org/10.1016/S0011-9164(00)00151-X

BRICIU, R. D.; KOT-WASIK, A.; NAMIESNIK, J. Analytical challenges and recent advances in the determination of estrogens in water environments. Journal of Chromatographic Science, v. 47, n. 2, p. 127-139, 2009. https://doi.org/10.1093/chromsci/47.2.127

CALDWELL, D. J.; MASTROCCO, F.; ANDERSON, P. D.; LÄNGE, R.; SUMPTER, J. P. Predicted-no-effect concentrations for the steroid estrogens estrone, 17 $\beta$-estradiol, estriol, and $17 \alpha$-ethinylestradiol. Environmental Toxicology and Chemistry, v. 31, n. 6, p. 1396-1406, 2012. https://doi.org/10.1002/etc.1825

CHEN, Q.; LI, Z.; HUA, X. Fate of estrogens in a pilot-scale step-feed anoxic/oxic wastewater treatment system controlling by nitrogen and phosphorus removal. Environmental Science and Pollution Research, v. 25, n. 13, p. 12981-12991, 2018. https://doi.org/10.1007/s11356-018-1584-3 
COGLIANO, V.; GROSSE, Y.; BAAN, R.; STRAIF, K.; SECRETAN, B.; GHISSASSI, F. E. Carcinogenicity of combined oestrogen-progestagen contraceptives and menopausal

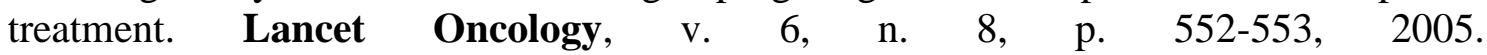
HTTPS://DOI.ORG/10.1016/s1470-2045(05)70273-4

COMBALBERT, S.; HERNANDEZ-RAQUET, G. Occurrence, fate, and biodegradation of estrogens in sewage and manure. Applied Microbiology and Biotechnology, v. 86, n. 6, p. 1671-1692, 2010. HTTPS://DOI.ORG/10.1007/s00253-010-2547-x

CUNHA, D. L.; PAUlA, L. M.; SILVA, S. M. C.; BILA, D. M.; FONSECA, E. M.; OLIVEIRA, J. L. M. Ocorrência e remoção de estrogênios por processos de tratamento biológico de esgotos. Revista Ambiente \& Água, v. 12, p. 249-262, 2017. HTTPS://DOI.ORG/10.4136/ambi-agua.1992

CUNHA, D. L.; SILVA, S. M. C.; BILA, D. M.; OLIVEIRA, J. L. M.; SARCINELLI, P. N.; LARENTIS, A. L. Regulamentação do estrogênio sintético 17士-etinilestradiol em matrizes aquáticas na Europa, Estados Unidos e Brasil. Cadernos de Saúde Pública, v. 32, n. 3, p. 1-13, 2016. HTTPS://DOI.ORG/10.1590/0102-311X00056715

ECOLOGIENA. Ethynylestradiol(EE2) ELISA KIT (Microplate) User's Guide. Tokyo: Tokiwa Chemical Ind., 2017. Available: https://abraxis.eurofinstechnologies.com/media/6487/ethynylestradiol_ee2_plate-users-guide.pdf. Access: 2021.

GAIDO, K. W.; LEONARD, L. S.; LOVELL, S.; GOULD, J. C.; BABAI, D.; PORTIER, C. J.; McDONEELL, D. P. Evaluation of Chemicals with Endocrine Modulating Activity in a Yeast-Based Steroid Hormone Receptor Gene Transcription Assay. Toxicology and Applied Pharmacology, v. 143, n. 1, p. 205-212, 1997. HTTPS://DOI.ORG/10.1006/taap.1996.8069

GARMSHAUSEN, J.; KLOAS, W.; HOFFMANN, F. 17 $\alpha$-Ethinylestradiol can disrupt hemoglobin catabolism in amphibians. Comparative Biochemistry and Physiology C-

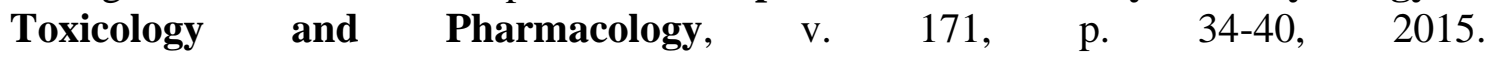
HTTPS://DOI.ORG/10.1016/j.cbpc.2015.03.004

GAVRILESCU, M.; DEMNEROVÁ, K.; AAMAND, J.; AGATHOS, S.; FAVA, F. Emerging pollutants in the environment: present and future challenges in biomonitoring, ecological risks and bioremediation. New Biotechnology, v. 32, n. 1, p. 147-156, 2015. HTTPS://DOI.ORG/10.1016/j.nbt.2014.01.001

GHEKIERE, A.; VERDONCK, F.; CLAESSENS, M.; MONTEYNE, E.; ROOSE, P.; WILLE, K.; GOFFIN, A.; RAPPÉ, K.; JANSSEN, C. R. Monitoring micropollutants in marine waters, can quality standards be met? Marine Pollution Bulletin, v. 69, n. 1, p. 243-250, 2013. HTTPS://DOI.ORG/10.1016/j.marpolbul.2012.12.024

GIUSTI, A.; LAGADIC, L.; BARSI, A.; THOMÉ, J.-P.; JOAQUIM-JUSTO, C.; DUCROT, $\mathrm{V}$. Investigating apical adverse effects of four endocrine active substances in the freshwater gastropod Lymnaea stagnalis. Science of the Total Environment, v. 493, p. 147-155, 2014. HTTPS://DOI.ORG/10.1016/j.scitotenv.2014.05.130

HASHIMOTO, T.; MURAKAMI, T. Removal and degradation characteristics of natural and synthetic estrogens by activated sludge in batch experiments. Water Research, v. 43, n. 3, p. 573-582, 2009. HTTPS://DOI.ORG/10.1016/j.watres.2008.10.051 
HUANG, C-H.; SEDLAK, D. L. Analysis of estrogenic hormones in municipal wastewater effluent and surface water using enzyme-linked immunosorbent assays and gas chromatography/tandem mass spectrometry. Environmental Toxicology and $\begin{array}{lllllll}\text { Chemistry, } & \text { v. } & 20, & \text { n. } & 1, & \text { p. } & 133-139,\end{array}$ HTTPS://DOI.ORG/10.1897/1551(2001)020<0133:AOEHIM>2.0.CO;2

HUERTA, B.; RODRIGUEZ-MOZAZ, S.; BARCELO, D. Pharmaceuticals in biota in the aquatic environment: analytical methods and environmental implications. Analytical and $\begin{array}{lllllll}\text { Bioanalytical Chemistry, } & \text { v. 404, n. 9, p. 2611-2624, } 2 .\end{array}$ HTTPS://DOI.ORG/10.1007/s00216-012-6144-y

IARC. Combined Estrogen-Progestogen Contraceptives and Combined Estrogen-Progestogen Menopausal Therapy. Lyon: WHO, 2007. p. 543. (IARC Monographs on the Evaluation of Carcinogenic Risks to Humans, 91).

JAFARI, A. J.; SALEHZADEH, A.; SALEHZADEH, A. Endocrine disrupting contaminants in water resources and sewage in Hamadan city of Iran. Journal of Environmental Health Science \& Engineering, v. 6, p. 89-96, 2009.

JIN, X.; ZHA, J.; XU, Y.; GIESY, J. P.; RICHARDSON, K. L.; WANG, Z. Derivation of predicted no effect concentrations (PNEC) for 2,4,6-trichlorophenol based on Chinese resident species. Chemosphere, v. 86, n. 1, p. 17-23, 2012. HTTPS://DOI.ORG/10.1016/j.chemosphere.2011.08.040

JOHNSON, A. C.; BELFROID, A.; DI CORCIA, A. D. Estimating steroid oestrogen inputs into activated sludge treatment works and observations on their removal from the effluent. Science of the Total Environment, v. 256, n. 2-3, p. 163-173, 2000. HTTPS://DOI.ORG/10.1016/s0048-9697(00)00481-2

JORGENSEN, S. E.; HALLING-SORENSEN, B. Drugs in the environment. Chemosphere, v. 40, n. 7, p. 691-699, 2000. HTTPS://DOI.ORG/10.1016/s0045-6535(99)00438-5

JOSS, A.; ANDERSEN, H.; TERNES, T.; RICHLE, P. R.; SIEGRIST, H.. Removal of Estrogens in Municipal Wastewater Treatment under Aerobic and Anaerobic Conditions: Consequences for Plant Optimization. Environmental Science and Technology, v. 38, n. 11, p. 3047-3055, 2004. HTTPS://DOI.ORG/10.1021/es0351488

KASNER, C. Advanced Wastewater Treatment by Nanofiltration and Activated Carbon for High Quality Water Reuse. 2011. 206 f. Dissertation (Grades eises Doktors) Hochschule Aachen, Aachen, Deutschland, 2011. Available: http://publications.rwthaachen.de/record/65381/files/4230.pdf. Access: 2021.

KOH, Y. K. K.; CHIU, T. Y.; BOOBIS, A.; CARTMELL, E.; SCRIMSHAW, M. D.; LESTER, J. N.. Treatment and Removal Strategies for Estrogen from Wastewater. Environmental $\begin{array}{lllllll}\text { Technology, } & \text { v. } & 29, & \text { n. } & 3, & \text { p. } & 245-267,\end{array}$ HTTPS://DOI.ORG/10.1080/09593330802099122

LAI, K. M.; SCRIMSHAW, M. D.; LESTER, J. N. Prediction of the bioaccumulation factors and body burden of natural and synthetic estrogens in aquatic organisms in the river systems. Science of the Total Environment, v. 289, n. 1-3, p. 159-168, 2002. HTTPS://DOI.ORG/10.1016/s0048-9697(01)01036-1

LAM, P. K.; GRAY, J. S. Predicting effects of toxic chemicals in the marine environment.

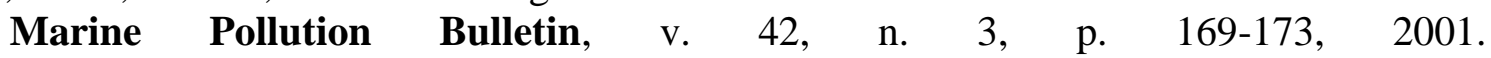
HTTPS://DOI.ORG/10.1016/S0025-326X(00)00178-8 
LI, C.; GU, Z.; ZHU, S.; LIU, D. 17 $\beta$-Estradiol removal routes by moving bed biofilm reactors (MBBRs) under various $\mathrm{C} / \mathrm{N}$ ratios. Science of the Total Environment, v. 741, p. 140381, 2020. HTTPS://DOI.ORG/10.1016/j.scitotenv.2020.140381

LIPORONI, L. M. Estudo preliminar da qualidade da água do Lago Paranoá, Brasília DF, utilizando um modelo de qualidade da água bidimensional. 2012, 209f. Dissertação (Mestrado em Tecnologia Ambiental e Recursos Hídricos), Universidade de Brasília, Brasília, 2012. Available: https://repositorio.unb.br/handle/10482/11925.

LUCENA, W. S. Determinação De Estrogênios Em Afluentes Da Lagoa De Araruama. 2013. 86 f. Dissertação (Mestrado em Saúde Pública e Meio Ambiente). Escola Nacional de Saúde Pública, FIOCRUZ, Rio de Janeiro, 2013. Available: https://www.arca.fiocruz.br/handle/icict/24300

LUNA, T. O.; STEPHANIE C. PLAUTZ; SALICE, C. J. Chronic Effects of $17 \alpha-$ Ethinylestradiol, Fluoxetine, and the Mixture on Individual and Population-Level End Points in Daphnia magna. Archives of Environmental Contamination and Toxicology, v. 68, n. 4, p. 603-611, 2015. HTTPS://DOI.ORG/10.1007/s00244-014-0119-2

LUO, Y.; GUO, W.; NGO, H. H.; NGHIEM, L. D.; HAI, F. I.; ZHANG, J.; LIANG, S.; WANG, X. C. A review on the occurrence of micropollutants in the aquatic environment and their fate and removal during wastewater treatment. Science of the Total $\begin{array}{lllll}\text { Environment, } & 473-474, & \text { p. } & 619-641,\end{array}$ HTTPS://DOI.ORG/10.1016/j.scitotenv.2013.12.065

METCALFE, C. D.; METCALFE, T. L.; KIPARISSIS, Y.; KOENIG, B. G.; KHAN, C.; HUGHES, R. J.; CROLEY, T. R.; MARCH, R. E.; POTTER, T.. Estrogenic potency of chemicals detected in sewage treatment plant effluents as determined by in vivo assays with Japanese medaka (Oryzias latipes). Environmental Toxicology and Chemistry, v. 20, n. 2, p. 297-308, 2001. HTTPS://DOI.ORG/10.1002/etc.5620200210

PESSOA, G. P.; DE SOUZA, N. C.; VIDAL, C. B.; ALVES, J. A. C.; FIRMINO, P. I. M.; NASCIMENTO, R. F.; dos SANTOS, A. B. Occurrence and removal of estrogens in Brazilian wastewater treatment plants. Science of the Total Environment, v. 490, p. 288-295, 2014. HTTPS://DOI.ORG/10.1016/j.scitotenv.2014.05.008

QUEIROZ, F. B.; BRANDT, E. M.; AQUINO, S. F.; CHERNICHARO, C. A.; AFONSO, R. J. C. F. Occurrence of pharmaceuticals and endocrine disruptors in raw sewage and their behavior in UASB reactors operated at different hydraulic retention times. Water Science $\begin{array}{lllllll}\text { and Technology, } & \text { v. 66, n. 12, } & \text { p. 2562-2569, }\end{array}$ HTTPS://DOI.ORG/10.2166/wst.2012.482

ROBINSON, B. J.; HELLOU, J. Biodegradation of endocrine disrupting compounds in harbour seawater and sediments. Science of the Total Environment, v. 407, n. 21, p. 5713-5718, 2009. HTTPS://DOI.ORG/10.1016/j.scitotenv.2009.07.003

SILVA, C. P.; LIMA, D. L. D.; SCHNEIDER, R. J.; OTERO, M.; ESTEVES, V. I.. Development of ELISA methodologies for the direct determination of $17 \beta$-estradiol and $17 \alpha$-ethinylestradiol in complex aqueous matrices. Journal of Environmental $\begin{array}{lllll}\text { Management, } & \text { v. } & 124, & \text { p. } & 121-127,\end{array}$ HTTPS://DOI.ORG/10.1016/j.jenvman.2013.03.041 
SILVA, S. R. Quantificação de substâncias com atividade estrogênica e caracterização da toxicidade embriolarval em zebrafish (Danio rerio) nos efluentes das estações de tratamento de esgotos sul e norte e no Lago Paranoá, Brasília-DF. 2015. $274 \mathrm{f}$. Dissertação (Mestrado em Biologia Animal) - Universidade de Brasília, Brasília, 2015. Available: https://repositorio.unb.br/bitstream/10482/18847/1/2015_SandraRitaSilva.pdf

SODRÉ, F. F.; SAMPAIO, T. R. Development and application of a SPE-LC-QTOF method for the quantification of micropollutants of emerging concern in drinking waters from the Brazilian capital. Emerging Contaminants, v. 6, p. 72-81, 2020. HTTPS://DOI.ORG/10.1016/j.emcon.2020.01.001

SODRÉ, F. F.; SANTANA, J. S.; SAMPAIO, T. R.; BRANDÃO, C. C. S. Seasonal and Spatial Distribution of Caffeine, Atrazine, Atenolol and DEET in Surface and Drinking Waters from the Brazilian Federal District. Journal of the Brazilian Chemical Society, v. 29, p. 1854-1865, 2018. HTTPS://DOI.ORG/10.21577/0103-5053.20180061

STANCZYK, F. Z.; ARCHER, D. F.; BHAVNANI, B. R. Ethinyl estradiol and 17ß-estradiol in combined oral contraceptives: pharmacokinetics, pharmacodynamics and risk assessment. $\begin{array}{llllllll}\text { Contraception, } & \text { v. } & 6, & 87, & \text { n. } & 6, & \text { p. } & 706-727,\end{array}$ HTTPS://DOI.ORG/10.1016/j.contraception.2012.12.011

SVENSON, A.; ALLARD, A. S.; EK, M. Removal of estrogenicity in Swedish municipal sewage treatment plants. Water Research, v. 37, n. 18, p. 4433-4443, 2003. HTTPS://DOI.ORG/10.1016/s0043-1354(03)00395-6

TIEDEKEN, E. J.; TAHAR, A.; MCHUGH, B.; ROWAN, N. J. Monitoring, sources, receptors, and control measures for three European Union watch list substances of emerging concern in receiving waters - A 20year systematic review. Science of the Total Environment, v. 574, p. 1140-1163, 2017. HTTPS://DOI.ORG/10.1016/j.scitotenv.2016.09.084

USEPA. Environmental Technology Verification Report: Abraxis Ecologenia (Trade Name) Ethynylestradiol (EE2) Microplate Enzyme-Linked Immunosorbent Assay (ELISA) Test Kit. Washington, DC., 2009. p. 34. Available: https://ntrl.ntis.gov/NTRL/dashboard/searchResults/titleDetail/PB2010103492.xhtml\#.

VADER, J. S.; VAN GINKEL, C. G.; SPERLING, F. M. G. M.; JONG, J.; BOER, W.; GRAAF, J. S.; VAN DER MOST, M; STOKMAN, P. G. Degradation of ethinyl estradiol by nitrifying activated sludge. Chemosphere, v. 41, n. 8, p. 1239-1243, 2000. HTTPS://DOI.ORG/10.1016/S0045-6535(99)00556-1

VAN VLAARDINGEN, P. L. A.; DE POORTER, L. R. M.; FLEUREN, R. H. L. J.; JANSSEN, P. J. C. M.; POSTHUMA-DOODEMAN, C. J. A. M.; VERBRUGGEN, E. M. J.; VOS, J. H. Environmental risk limits for twelve substances, prioritised on the basis of indicative risk limits. Bilthoven: National Institute for Public Health and the Environment, 2007. 230 p. (RIVM Report 601782003/2007). Available: https://www.rivm.nl/bibliotheek/rapporten/601782003.pdf

VON SPERLING, M. Princípios do tratamento biológico de águas residuárias: lodos ativados. Belo Horizonte: UFMG, 2012.

WHO. State of the Science of Endocrine Disrupting Chemicals-2012. Geneva, 2013. Available: www.who.int/iris/bitstream/10665/78101/1/9789241505031_eng.pdf?ua=1

ZHANG, Y.; ZHOU, J. L. Occurrence and removal of endocrine disrupting chemicals in

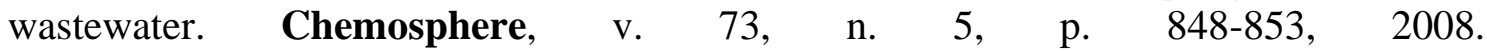
HTTPS://DOI.ORG/10.1016/j.chemosphere.2008.06.001 